\title{
Insights into normal myelopoiesis
}

\author{
DENNIS G OSMOND, MB, CHB, DSC, FRSC
}

\begin{abstract}
DG Osmond. Insights into normal myelopoiesis. Can J Infect Dis 1992;3(Suppl B):69B-75B. Recent in vivo studies provide working models of cell production and cell loss in myelopoiesis, as exemplified by B lymphopoiesis in mouse bone marrow. The process is susceptible to both local and systemic regulatory influences and shows a complex tissue organization. Early precursor cells tend to be located in microenvironments towards the edge of the bone marrow near the surrounding bone. Differentiating precursor cells adhere to local stromal reticular cells, representing a cellular interaction which is essential for further B cell development. Many defective or unacceptable B precursor cells are selected out and deleted by resident bone marrow macrophages. Maturing B cells congregate in segments of venous sinusoids before being released into the blood circulation. Rapid progress is being made in elucidating the nature of the cytokines, extracellular matrix and cell adhesion molecules involved in normal regulation and perturbations of primary B lymphopoiesis in vivo.
\end{abstract}

Key Words: Bone Marrow, B Lymphocyte production, Myelopoiesis, Pre-B cells, Pro-B cells, Stromal cells

\section{La myélopoïèse normale: Une analyse approfondie}

RÉSUMÉ: Des études in vivo récentes fournissent des modèles fonctionnels de la production et de la perte des cellules en cours de myélopoïèse, ainsi que l'illustre la lymphopoïèse B de la moelle osseuse de la souris. Ce processus est sensible à des functions de régulation locale et systémique et démontre une organisation tissulaire complexe. Les jeunes cellules précurseurs se retrouvent dans les microenvironnements situés à la périphérie de la moelle osseuse, à proximité de l’os. Les cellules précurseurs en voie de se différencier adhèrent aux cellules réticulaires stromales locales. Cette interaction cellulaire semble essentielle à l'êvolution des lymphocytes B. Un grand nombre de cellules précurseurs B défectueuses ou inacceptables sont repérées et éliminées par les macrophages résidents de la moelle osseuse. Les lymphocytes B en voie de maturation se rassemblent dans des segments de capillaires sinusoïdes avant d'être libérés dans la circulation sanguine. L'evolution rapide de vos connaissances va nous permettre d'élucider la nature des cytokines, de la matrice extracellulaire et des molécules d'adhérence cellulaires qui régissent la régulation normale et les perturbations de la lymphopoïèse B in vivo.

Department of Anatomy, McGill University, Montreal, Quebec

Correspondence and reprints: Dr DG Osmond, Department of Anatomy, McGill University, 3640 University Street, Montreal, Quebec H3A 2B2. Telephone (514) 398-6355, Fax (514) 398-5047 
C ELL PRODUCTION IN THE BONE MARROW PROVIDES CONtinuous renewal of several distinct lineages of cells. Recent work emphasizes that this process depends upon the activities of a variety of local tissue elements and regulatory molecules. This report considers: the recognition of differentiation stages through which renewing cells pass: some systemic and local regulatory mechanisms; and emerging evidence for the role of an organized tissue microenvironment in the bone marrow. As a model of myelopoiesis, this article focuses on work in the author's laboratory on the production of B lymphocytes in mouse bone marrow. This process supplies virgin B cells to maintain primary humoral immunity in the immune system. Although particular features are unique to the $\mathrm{B}$ cell lineage, the general principles apply broadly to the other myelopoietic lineages which generate monocytes, granulocytes, erythrocytes and thrombocytes.

\section{DIFFERENTIATION COMPARTMENTS}

Stem cells: In a renewal system, such as myelopoiesis, individual cells pass through a series of differentiation stages. There is, first, a small number of stem cells which are capable of self-renewal and of differentiating into progenitors which become committed to one particular cell lineage. The committed progenitor cells can proliferate extensively, giving rise to much larger numbers of nondividing mature cells, destined to die after a limited life span. The magnitude of cell production is regulated mainly by growth factors acting at the stage of the proliferating progenitor cells.

Hemopoietic stem cells appear to represent a hierarchy of several types. Some stem cells are pluripotential and can give rise to all of the hemopoietic and lymphocytic cell lineages when transferred to lethally irradiated recipients (1). Other self-renewing categories of stem cells have more restricted ('myeloid') potentials, giving rise only to erythroid, granulocytic and monocyte-macrophage lineages. These stem cells are identified by giving rise to colonies in the spleens of irradiated recipients or to mixed lineage colonies in vitro (2). Such cells have been considerably enriched by multiparameter flow cytometry and cell sorting (3). Evidence for self-renewing stem cells restricted to the lymphocytic lineages is emerging from work on long term bone marrow cultures and the use of retrovirusmarked bone marrow cells in reconstitution experiments $(4,5)$.

Precursor cells in B lymphopoiesis: The recognition of cell lineage-associated molecules and differentiation-related markers has allowed phenotypic stages in cell renewal to be identified. In the case of B lymphopoiesis in mouse bone marrow, three molecular markers have been used; the $\mu$ heavy chain of immunoglobulin $\mathrm{M}$ (IgM), a molecule specific for the B cell lineage; B220 glycoprotein, a B cell-associated cell surface molecule in mice, detected by monoclonal antibodies; and ter- minal deoxynucleotidyl transferase (Tdt), an intranuclear enzyme which is expressed during the stage of Ig heavy chain gene rearrangements, acting to insert additional nucleotides at the junctions between Ig gene segments $(6,7)$. The expression of the three molecules has been examined in double marker combinations, using fluorescence labelling of cell suspensions, analysed by epifluorescence microscopy of cytocentrifuged preparations. Using these techniques, six phenotypic stages of differentiation have been identified (Figure 1) (8).

Mature B cells are recognized by surface IgM in the cell membrane. They are preceded by pre-B cells that have cytoplasmic free $\mu$ chains but no cell surface $\mu$. All pre-B cells and B cells also express B220. These late stages of $\mathrm{B}$ cell genesis are well established. Large pre-B cells divide to give rise to nondividing small pre-B cells which mature into nondividing small B lymphocytes. The earlier progenitors, however, have been more controversial. Such progenitor cells, before the expression of the $\mu$ heavy chain, can be termed, pro-B cells. Three subsets of $\mu$ negative cells have been identified as candidate pro-B cells, based on the expression of TdT and B220: early pro-B cells ( $\mathrm{TdT}^{+} \mathrm{B} 2207$ ); intermediate


$\mathrm{B}^{2} 2 \mathrm{O}^{+}$). This proposed sequence of development accords with data so far available, including quantitation of the individual cell populations in normal bone marrow (6-8) and the sequence of regeneration during recovery from ionizing irradiation (9).

Cell production and loss in B cell genesis: The population dynamics of precursor cell populations have been studied in vivo. The dividing pro-B cells and large pre-B cells have been examined by mitotic arrest techniques, revealing the rate at which cells enter mitosis (6-8), while the renewal rates of the nondividing small pre- $\mathrm{B}$ cells and B cells have been measured by DNA labelling techniques $(8,10,11)$. The results emphasize that two opposing processes take place simultaneously, cell production and cell loss.

Considerable proliferative expansion occurs in early stages of precursor cell development. The total flow of cells through cell cycle in each differentiation compartment per unit time apparently doubles from the early to intermediate pro- $\mathrm{B}$ cell stages and then increases sevenfold at the late pro-B cell stage $(7,8)$. At least one mitosis occurs at each of the pro-B cell and large pre-B cell stages, while the observed expansion of dividing late pro-B cells suggests that there may be as many as three mitoses at this stage. If so, a total of six mitoses would occur between the rearrangement of $\mu$ heavy chain genes and the emergence of the mature B cells, representing a potential clone of 64 cells of any given $\mu$ chain specificity.

In addition to cell proliferation, however, the population dynamics suggest a substantial cell loss $(8,12)$. The calculated output from the large pre-B cell population 
is greater than the flow of cells actually observed in the next two compartments. This suggests an extensive loss of cells, equivalent to approximately $70 \%$ of the total cell production, at this point. In the B cell lineage, such cell loss probably represents the abortion of cells which have undergone ineffective gene rearrangement, a process prone to genetic error, as well as the deletion of some cells with potentially autoreactive specificities (13). Degrees of ineffective cell production also characterize the other lineages of myelopoiesis. The output of mature cells from the bone marrow is thus a balance between processes of cell production and cell deletion.

\section{REGULATION OF PRECURSOR CELL PROLIFERATION}

The normal population dynamics of $B$ cell genesis provide a model on which to examine perturbations and possible control mechanisms in vivo.

Feedback control: The possible existence of a feedback regulatory mechanism in B cell genesis has been examined in two immunodeficient states in which mature $B$ cells are absent. First, mice treated from birth with anti-IgM antibodies develop no $\mathrm{B}$ cells. In the bone marrow, B lineage cells are deleted completely, just as they are about to express surface IgM (14). Second, mutant mice with severe combined immunodeficiency (scid) are unable successfully to rearrange Ig heavy chain genes, and all precursor cells are deleted during the late pro-B cell stage (15). Nevertheless, in both of these conditions, the production rates of the residual $B$ lineage precursor cells in the bone show no overall elevation. Despite the lack of B cells there appears to be no evidence of compensatory hyperplasia in the bone marrow indicative of a feedback humoral control such as would be the case, for example, in erythropoiesis.

External environmental agents and systemic factors: Germ free mice show a reduced level of bone marrow lymphocytopoiesis. On the other hand, conventional mice injected with a variety of agents, eg, sheep red blood cells, show increased proliferation of pro-B cells and pre-B cells and an increased production of $B$ lymphocytes in the bone marrow (16-18). These effects are abrogated completely by treating the mice with silica particles to depress macrophage function, or by splenectomy. These findings indicate that the stimulatory effects of sheep red blood cell injections on B cell genesis are mediated by the activation of macrophages apparently located in the spleen, suggesting the existence of systemic proliferative factors acting on the precursor cells in the bone marrow. Thus, the final level of B cell genesis in the bone marrow appears to reflect the sum total of external environmental stimuli, probably a polyclonal amplifying effect.

The suggestion that the products of activated macrophages may lead to a stimulation of precursor B cells in the bone marrow has prompted the examination of the effects of two conditions of chronic excessive macrophage activation as seen in murine malaria and follow-

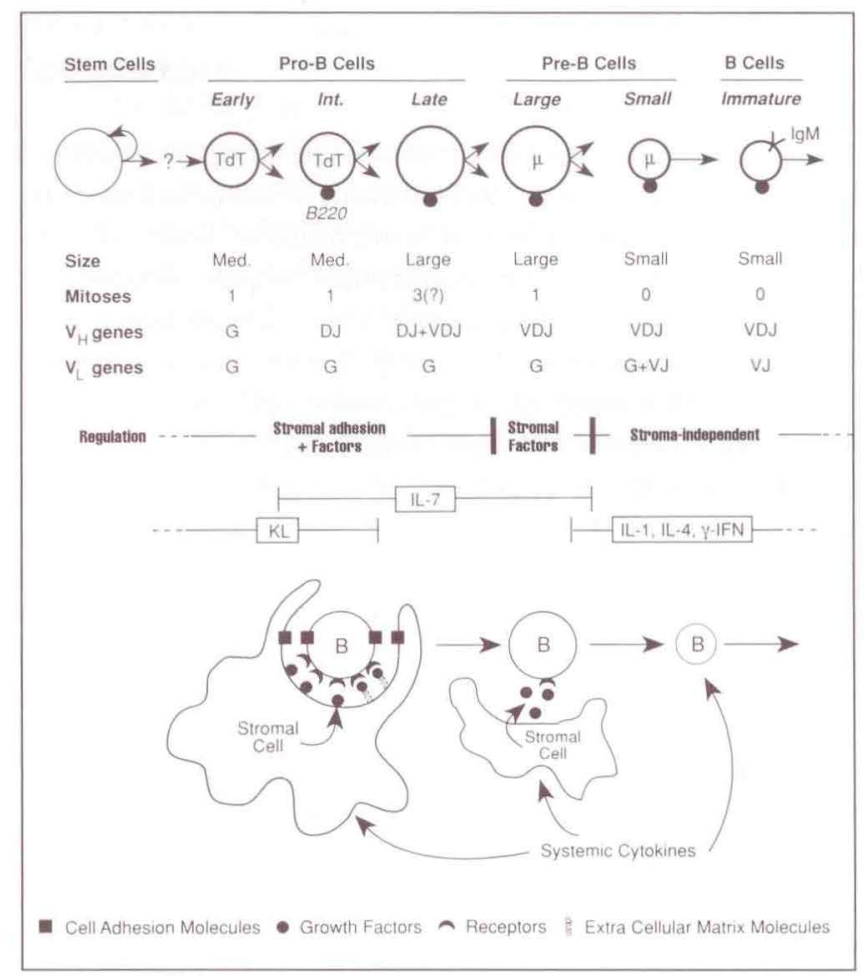

Figure 1) Scheme of differentiation compartments, regulating factors and stromal cell associations of precursor B cells in bone marrow

ing the intraperitoneal injection of pristane mineral oil. These conditions produce high levels of macrophage activation, associated with malarial splenomegaly and oil-induced granulomas, respectively. Both malaria in humans and pristane oil administration in mice are preneoplastic conditions which can lead to the development of B cell lineage neoplasia, viz Burkitt's lymphoma and murine plasmacytoma, respectively, often associated with the same genetic error, an Ig/myc translocation $(19,20)$. Despite their different nature, these agents both produce a similar effect on B lymphocytopoiesis in the bone marrow (21). The production rates of early progenitors, the $\mathrm{TdT}^{+}$pro-B cell stages, are increased, but those of later precursor cell stages are either normal or decreased. This effect is persistent, lasting many weeks or months. The findings suggest that in each case there is a stimulation of production of pro-B cells at the stage of Ig heavy chain gene rearrangement which is followed, however, by an increased cell loss. It may be speculated that in each of these systems the stimulation of precursor cells which are in the process of rearranging Ig genes may increase the chances of genetic errors. Some of these would lead to an increased deletion of aberrant cells. On the other hand, some cells with errors could survive and go to the periphery where they could represent the first in a series of steps in neoplastic dysregulation. Thus, B cell genesis in the bone marrow appears to be susceptible to systemic effects, a process which may also have an oncogenic 
significance. A more fundamental control of B cell genesis, however, appears to take place within the local tissue microenvironment.

Local regulatory mechanisms: Bone marrow cells can be cultured for long periods of time in vitro, but only in conjunction with a layer of bone marrow stromal cells $(22,23)$. Under culture conditions which support B lymphopoiesis, the B precursor cells cluster over some stromal cells but not others (24). There appears to be a selective adherence of $\mathrm{B}$ precursor cells to a certain subset of stromal cells, from which they receive critical supportive stimuli. B cell supportive stromal cell lines have been cloned and various stromal cell derived factors are under investigation $(24,25)$. The author has been examining the local tissue interactions of $\mathrm{B}$ cell genesis in vivo, a subject about which virtually nothing has been known.

\section{MICROENVIRONMENTAL ORGANIZATION OF B LYMPHOPOIESIS IN VIVO}

Tissue sections of mouse femora show the bone marrow to be organized around the blood circulation. From the centre of the marrow, arteries radiate to a subendosteal capillary plexus, from which the blood drainage returns through large venous sinusoids converging towards a central venous sinus. The bone marrow thus has both an extravascular hemopoietic compartment, and an extensive intravascular space.

The author has developed methods to label B lineage cells within mouse bone marrow in situ by administering radiolabelled monoclonal antibodies intravenously $(26,27)$. Radioautography of monoclonal antibodybinding cells in sections of femoral marrow reveals surface $\mathrm{IgM}^{+} \mathrm{B}$ cells and $\mathrm{B} 22 \mathrm{O}^{+} \mathrm{B}$ lineage cells in the extravascular compartment. At the electron microscope level, radioautographs show labelling of high specificity and fine resolution over the cell surface membrane as well as revealing the tissue localization and immediate associations of the identified B lineage cells. The findings point to a centripetal gradient of differentiation, important associations with stromal cells, interactions with macrophages and a final intravascular phase of development.

Differentiation gradient: While B lineage cells are distributed throughout mouse bone marrow, the mature B cells tend to be concentrated mainly towards the centre of the bone marrow near the central sinus, whereas the early precursors predominate more peripherally near the bone (26-28). Proliferating clusters of $\mathrm{B}_{2} 20^{+}$pro-B cells are situated peripherally adjacent to the bone matrix interface during the early stages of regeneration of the $\mathrm{B}$ cell lineage after sublethal gammairradiation (29). In scid mice, many of the early $\mathrm{B}_{2} 2 \mathrm{O}^{+}$ lineage cells are found among the peripheral bone lining cell layers (15). A similar peripheral distribution has been reported for other hemopoietic precursors, CFU-S and CFU-C (30). A special microenvironment for early hemopoietic progenitor cells appears to exist in the outer bone-associated area.

Stromal cell associations and molecular interactions: B lineage cells are intimately associated with stromal reticular cells in vivo $(27,29)$. Labelled $\mathrm{B} 220^{+}$ cells show extensive contact with the complex processes of stromal reticular cells which frequently appear virtually to encircle the B precursor cells. In some planes of section, several B precursor cells are seen on the surface of a single stromal reticular cell. Thus, individual B precursors apparently develop in close association with stromal cells in vivo, as they do in bone marrow cultures, suggesting that this represents the microenvironmental regulatory unit in B lymphopoiesis. A great deal of current interest concerns the role of extracellular matrix molecules and the nature of cell adhesion molecules that may bind the cells together, as well as local and systemic growth factors that may be operating at this level.

Extracellular matrix molecules identified by immunolabelling techniques in murine bone marrow include fibronectin produced by fibroblasts, laminin and collagen type IV in sinusoid endothelial cell basement membranes, and glycosaminoglycans, particularly heparin sulphate proteoglycan which has been shown locally to bind cytokines and thereby help to create a localized microenvironment for these factors $(31,32)$.

Adhesion molecules so far detected on B cell precursors in recent work include the hyaluronate receptor CD44, ICAM-1, and the integrins, VLA-4 and VLA-5 (33-36). The expression of VLA-4 occurs at sites of contact between precursor cells and stromal cells (37). B cell precursors express fibronectin receptors and syndecan while they are in an immature stage but these receptors disappear as the cells mature $(38,39)$. Similarly, B cell precursor cells bind avidly the lectin. peanut agglutinin, whereas mature B cells do not (40). The functional importance of adhesion molecules is indicated by observations in bone marrow cultures that the introduction of antibodies against either CD44 or VLA-4 causes the precursor cells and stromal cells to dissociate from one another and further B cell genesis is completely blocked $(33,34)$. Novel surface molecules are also being detected on the bone marrow stromal cells, using monoclonal antibodies raised against $\mathrm{B}$ cell-supportive stromal cell lines. One of these, (monoclonal antibody KMI.6), recognizing a $100 \mathrm{kDa}$ glycoprotein, is expressed on stromal cell processes in vivo, as well as on the stromal cell line in vitro, particularly at areas of contact with lymphoid cells (unpublished data). Rapid progress is expected in the field of stromal cell surface determinants.

Bone marrow stromal cells can produce a variety of growth factors (24,41-45). As revealed by mRNA expression, some, but not all, cloned stromal cell lines constitutively produce colony stimulating factors (CSF), certain interleukins (IL) (IL-4, IL-6, IL-7) or transform- 
ing growth factor-beta (TGF- $\beta$ ). Stromal cell populations thus appear to be heterogeneous with respect to growth factor secretion. They also reflect a complex inductive interaction between various cytokines. IL-1 can act upon bone marrow stromal cells, inducing them to produce a range of other cytokines, including IL-4, IL-6, IL-7 and CSFs. Conversely, the production of IL-6 by bone marrow stromal cells can be induced by a variety of other cytokines, including IL-1, IL-7, TGF- $\beta$ and tumour necrosis factor (TNF). Bone marrow stromal cells evidently carry cytokine receptors and can be regarded as an integral part of the cytokine network of the body.

According to its dependence upon growth factors, B lymphopoiesis in the bone marrow can be divided into three stages $(24,46)$ (Figure 1). At first, the early precursor cell stages (pro-B cells) require actual stromal cell contact. The molecular factors at this stage remain largely unknown. They may include IL-3, c-kit ligand (KL) and lymphopoietic factors which are as yet only partially defined. Next, the later pro-B cells and pre-B cells need the presence of stromal cells but an intimate adherence to stromal cells is no longer essential. At this stage, the most influential stromal cell factor so far defined is IL-7, a well-characterized $25 \mathrm{kDa}$ glycoprotein which produces intense proliferation of pro-B cells and pre-B cells (47-49). A factor present in the serum and urine of a patient with cyclic neutropenia also stimulates cells at this stage (50). Finally, the transition from pre-B cells to $\mathrm{B}$ cells is quite independent of stromal cells, but it can be accelerated by a variety of immune mediators (IL-1, IL-4, immune interferon-gamma) and a factor in the serum of New Zealand black mice $(24,51)$.

While most of the foregoing effects have been observed in cultured bone marrow, IL-7 has been reported to expand the populations of pre-B cells and B cells in the bone marrow when administered systemically, and the author is currently examining the proliferative effects of recombinant $\mathrm{IL}-7$ and $\mathrm{IL}-1$ in vivo. The continuous delivery of IL-7 from an osmotic minipump produces a sustained increase in proliferation of both pro-B cells and pre-B cells, while IL-1 administration causes a delayed stimulation of pre-B cells after an initial depression (unpublished data). These findings may have practical implications, showing that even cytokines like IL-7, which normally act as short range local factors, can also have stimulatory effects when administered systemically. Conversely, however, other hemopoietic growth factors given systemically may actually depress $\mathrm{B}$ cell genesis in the bone marrow. The administration of recombinant GM-CSF in vivo, which increases the genesis of granulocytic cells, produces a concomitant, though reversible, depression of central B cell genesis (52).

Macrophage interactions: Labelled $\mathrm{B} 22 \mathrm{O}^{+} \mathrm{B}$ precursor cells in mouse bone marrow are frequently observed to be associated with the cytoplasmic processes of macrophages, voluminous cells containing a variety of inclusions (27). The B precursor cells may exhibit an irregular nucleus with peripheral chromatin condensation and vacuolated electron-dense cytoplasm. These are the morphological manifestations of a programmed cell death, termed apoptosis. The characteristic DNA fragmentation of apoptosis has yet to be demonstrated.

Interaction of $\mathrm{B}^{2} 2 \mathrm{O}^{+}$cells with macrophages appears to represent the way in which many $B$ lineage cells die and are deleted in the bone marrow. More extreme examples of this process are seen in systems in which all B lineage cells abort. In scid mice and anti-IgMtreated mice the bone marrow is characterized by prominent macrophages containing many apoptotic residual bodies $(15,27)$.

Thus, two steps may be involved in B cell loss in the bone marrow. First, a signal is given to the cell leading to apoptosis. This initiating signal may be endogenous in origin, as in aberrant Ig gene rearrangements, or exogenous, as in the recognition of a self-reactive antigen. Second, the affected cell is apparently quickly recognized by macrophages, internalized and degraded. Thus, while stromal cell-associated control mechanisms are important in determining the level of cell production, macrophage-mediated cell deletion appears to be important in screening out defective or undesirable cells that potentially have deleterious effects if released from the bone marrow.

Intravascular B lineage cells: Some of the venous sinusoids in the bone marrow of mice and rats contain remarkable concentrations of surface IgM-bearing $\mathrm{B}$ cells (26.27). The observations suggest that maturing cells focus into segments of sinusoids, possibly being retained there for a period of further development, before they enter the general blood circulation of the body. The factors involved in this process and in the release of $\mathrm{B}$ cells from the extravascular compartment of the bone marrow are completely unknown.

\section{CONCLUSIONS}

The work reviewed briefly in this article provides working models of B lymphopoiesis in vivo (Figure 1), many general principles of which are broadly applicable to the other cell lineages of myelopoiesis. The early precursor cells, probably including stem cells, tend to be located in microenvironments around the edge of the bone marrow near the surrounding bone. As they begin to differentiate, the early B precursors associate with stromal reticular cells. This essential step in B cell development involves cell adhesion molecules and the interaction of stromal cell-derived growth factors and extracellular matrix molecules at the cell interface. In addition, the stromal cells appear to be responsive to the action of systemic cytokines. The precursor cells tend to move centrally in the bone marrow as they proliferate through successive mitotic cell cycles into an 
expanding pool of cells. Aberrant cells are removed in large numbers as they encounter the complex processes of resident macrophages en route. Viable B cells finally focus into segments of venous sinusoids from which they are released into the systemic blood circula-

ACKNOWLEDGEMENTS: This study was supported by grants from the Medical Research Council and the National Cancer Institute of Canada.

\section{REFERENCES}

1. Testa NG, Dexter TM. Cell lineages in haemopoiesis: Comments on their regulation. Semin Immunol 1990;2:167-72.

2. Jones RJ, Wagner JE, Celano P, Zicha MS, Sharkis SJ. Separation of pluripotent haematopoietic stem cells from spleen colony-forming cells. Nature 1990;347:188-9.

3. Spangrude GJ, Scollay R. A simplified method for enrichment of mouse hematopoietic stem cells. Exp Hematol 1990;18:920-6.

4. Fulop GM, Phillips RA. Identification and quantitation of lymphoid-restricted stem cells in long-term bone marrow cultures. Blood 1989:74:1537-44.

5. Dick JE, Magli MC, Phillips RA, Bernstein A. Genetic manipulation of hematopoietic stem cells with retrovirus vectors. Trends Genet 1986;2:165-70.

6. Park YH, Osmond DG. Phenotype and proliferation of early B lymphocyte precursor cells in mouse bone marrow. J Exp Med 1987;165:444-58.

7. Park YH, Osmond DG. Dynamics of early B lymphocyte precursor cells in mouse bone marrow: Proliferation of cells containing terminal deoxynucleotidyl transferase. Eur J Immunol 1989;19:2139-44.

8. Osmond DG. Proliferation kinetics and the lifespan of B cells in central and peripheral lymphoid organs. Curr Opin Immunol 1991;3:179-85.

9. Park YH, Osmond DG. Post-irradiation regeneration of early B-lymphocyte precursor cells in mouse bone marrow. Immunology 1989;66:343-7.

10. Osmond DG. Population dynamics of bone marrow B lymphocytes. Immunol Rev 1986;93:103-24.

11. Förster I, Vieira P, Rajewsky K. Flow cytometric analysis of cell proliferation dynamics in the B cell compartment of the mouse. Int Immunol 1989;1:321-31.

12. Deinen GJ, Van Balen I, Opstelten D. In rat B lymphocyte genesis sixty percent is lost from the bone marrow at the transition of nondividing pre-B cell to $\operatorname{IgM}^{+} \mathrm{B}$ lymphocyte, the stage of Ig light chain gene expression. Eur J Immunol 1990;20:557-64.

13. Nemazee DA, Bürki K. Clonal deletion of B lymphocytes in a transgenic mouse bearing anti-MHC class I antibody genes. Nature 1989;337:562.

14. Fulop G, Gordon J, Osmond DG. Regulation of lymphocyte production in the bone marrow. I. Turnover of small lymphocytes in mice depleted of B lymphocytes by treatment with anti-IgM antibodies. J Immunol 1983;130:644-8.

15. Osmond DG, Phillips RA, Kim N, Manoukian R, Jacobsen K, Rico-Vargas SA. Dynamics and localization of early B progenitor cells (pro- B cells) in the bone marrow of mice with severe combined immuno-deficiency (scid). Blood 1992;79:1695-1703.

16. Fulop GM, Osmond DG. Regulation of bone marrow lymphocyte production. IV. Cells mediating the stimulation of marrow lymphocyte production by sheep red blood cells: Studies in anti-IgM-suppressed mice, athymic mice, and tion by signals which are not yet understood. These working models, consistent with information currently available, provide a basis for continuing work on regulatory factors and perturbations of B lymphopoiesis in vivo.

silica-treated mice. Cell Immunol 1983;75:91-102.

17. Pietrangeli CE, Osmond DG. Regulation of B-lymphocyte production in the bone marrow: Mediation of the effects of exogenous stimulants by adoptively transferred spleen cells. Cell Immunol 1987; 107:348-57.

18. Park YH, Osmond DG. Regulation of early precursor B cell proliferation in mouse bone marrow: Stimulation by exogenous agents mediated by macrophages in the spleen. Cell Immunol 1991;135:168-83.

19. Klein G, Klein E. Conditioned tumorigenicity of activated oncogenes. Cancer Res 1986;46:3211-24.

20. Potter M, Mushinski JF, Mushinski EB, et al. Avian $\mathrm{v}$-myc replaces chromosomal translocation in murine plasmacytomagenesis. Science 1987;235:787-9.

21. Osmond DG, Priddle S, Rico-Vargas S. Proliferation of B cell precursors in bone marrow of pristane-conditioned and malaria-infected mice: Implications for B cell oncogenesis. Curr Top Microbiol Immunol 1990;166:149-57.

22. Yamazaki K, Zacharov Y, Simmons PJ, Dexter TM, Allen TD. A comparative morphometric study on the ultrastructure of adherent cells in long-term bone marrow culture from normal and congenitally anemic mice. Blood Cells 1989; 15:343-64.

23. Hunt P, Robertson D, Weiss D, Rennick D, Lee F, Witte ON. A single bone marrow-derived stromal cell type supports the in vitro growth of early lymphoid and myeloid cells. Cell 1987;48:997-1007.

24. Kincade PW, Lee G, Pietrangeli CE, Hayashi SI, Gimble JM. Cells and molecules that regulate B lymphopoiesis in bone marrow. Ann Rev Immunol 1989;7:111-43.

25. Pietrangeli CE, Hayashi SI, Kincade PW. Stromal cell lines which support lymphocyte growth: Characterization, sensitivity to radiation and responsiveness to growth factors. Eur J Immunol 1988;18:863-72.

26. Batten SJ, Osmond DG. The localization of B lymphocytes in mouse bone marrow: Radioautographic studies after in vivo perfusion of radiolabeled anti-IgM antibody. J Immunol Meth 1984;72:381-99.

27. Jacobsen K, Osmond DG. Microenvironmental organization and stromal cell associations of B lymphocyte precursor cells in mouse bone marrow. Eur J Immunol 1990;20:2395-404.

28. Hermans MHA, Harsuiker H, Opstelten D. An in situ study of B-lymphocytopoiesis in rat bone marrow. Topographical arrangement of terminal deoxynucleotidyl transferase positive cells and pre-B cells. J Immunol 1989; 142:67-73.

29. Jacobsen K, Tepper J, Osmond DG. Early B-lymphocyte precursor cells in mouse bone marrow: Subosteal localization of $\mathrm{B}^{2} 2 \mathrm{O}^{+}$cells during postirradiation regeneration. Exp Hematol 1990:18:304-10.

30. Lord BI, Testa NG, Hendry JH. The relative spatial distribution of CFU-s and CFU-c in the normal mouse femur. Blood 1975;46:65-72.

31. Gordon M. Extracellular matrix of the marrow microenvironment. Br J Haematol 1988;70:1-4.

32. Roberts R, Gallagher J, Spooncer E, Allen TD, Bloomfield F, Dexter TM. Heparin sulfate bound growth factors: A mechanism for stromal cell mediated haemopoiesis. Nature 1988;332:376. 
33. Miyake K, Medina KL, Hayashi SI, Ono S, Hamaoka T, Kincade PW. Monoclonal antibodies to Pgp-1/CD44 block lympho-hemopoiesis in long-term bone marrow cultures. J Exp Med 1990;171:477-88.

34. Miyake K, Weissman IL, Greenberger JS, Kincade PW. Evidence for a role of the integrin VLA-4 in lympho-hemopoiesis. J Exp Med 1991; 173:599-607.

35. Miyake K, Medina K, Ishihara K, Kimoto M, Auerbach R, Kincade PW. A VCAM-like adhesion molecule on murine bone marrow stromal cells mediates binding of lymphocyte precursors in culture. J Cell Biol 1992;114:557-65.

36. Hemler ME. Adhesive protein receptors on hematopoietic cells. Immunol Today 1988;9:109-13.

37. Soligo D, Schiró R, Luksch R, et al. Expression of integrins in human bone marrow. Br J Haematol 1990;76:323-32.

38. Bernardi P, Patel VP, Lodish HF. Lymphoid precursor cells adhere to two different sites on fibronectin. J Cell Biol 1987; 105:489-98.

39. Sanderson RD, Lalor P, Bernfield M. B lymphocytes express and lose syndecan at specific stages of differentiation. Cell Regulation 1989;1:27-35.

40. Osmond DG. Pre-B cells in bone marrow: Peanut agglutinin binding and separation of cytoplasmic $\mu$ chain-bearing cell populations in normal, post-irradiation and polycythemic mice using fluorescence-activated cell sorting. Eur J Immunol 1984; 14:495-502.

41. Gimble JM, Pietrangeli C, Henley A, et al. Characterization of murine bone marrow and spleen derived stromal cells: Analysis of leukocyte markers and growth factor mRNA transcript levels. Blood 1989;74:303-11.

42. Simpson L, McNiece I, Newberg M, et al. Detection and characterization of a B cell stimulatory factor (BSF-TC) derived from a bone marrow stromal cell line. J Immunol 1989; 142:3894-900.

43. Kelso A. Cytokines: Structure, function and synthesis. Curr Opin Immunol 1989;2:215-25.

44. Mizel SB. The interleukins. FASEB 1989;3:2379-88.

45. Libert C, Brouchaert P, Shaw A, Fiers W. Induction of interleukin 6 by human and murine recombinant interleukin 1 in mice. Eur J Immunol 1990;20:691-4.

46. Hayashi SI, Kunisada T, Ogawa M, et al. Stepwise progression of B lineage differentiation supported by interleukin 7 and other stromal cell molecules. J Exp Med 1990;171:1683-95.

47. Namen AE, Schmierer AE, March CJ, et al. Purification and characterization of a growth factor active on lymphocyte precursors. J Exp Med 1988;167:988-1002.

48. Lee G, Namen AE, Gillis S, Ellingsworth LR, Kincade PW. Normal B cell precursors responsive to recombinant murine IL- 7 and inhibition of IL- 7 activity by transforming growth factor- $\beta$. J Immunol 1989; 142:3875-83.

49. Park LS, Friend DJ, Schmierer AE, Dower SK, Namen AE. Murine interleukin 7 (IL-7) receptor. Characterization on an IL-7-dependent cell line. J Exp Med 1990;171:1073-89.

50. Landreth KS, Engelhard D, Beare MH, Kincade PW, Kapoor N, Good RA. Regulation of human B lymphopoiesis: Effect of a urinary activity associated with cyclic neutropenia. J Immunol 1985; 134:2305-9.

51. King AG, Wierda D, Landreth KS. Bone marrow stromal cell regulation of B-lymphopoiesis. 1. The role of macrophages, IL-1 and IL-4 in pre-B cell maturation. J Immunol 1988;141:2016-26.

52. Dorshkind $\mathrm{K}$. In vivo administration of recombinant GM-CSF results in a reversible inhibition of primary B lymphopoiesis. J Immunol 1991; 146:4204-8. 


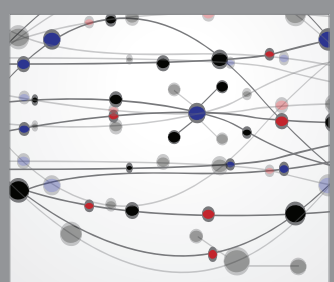

The Scientific World Journal
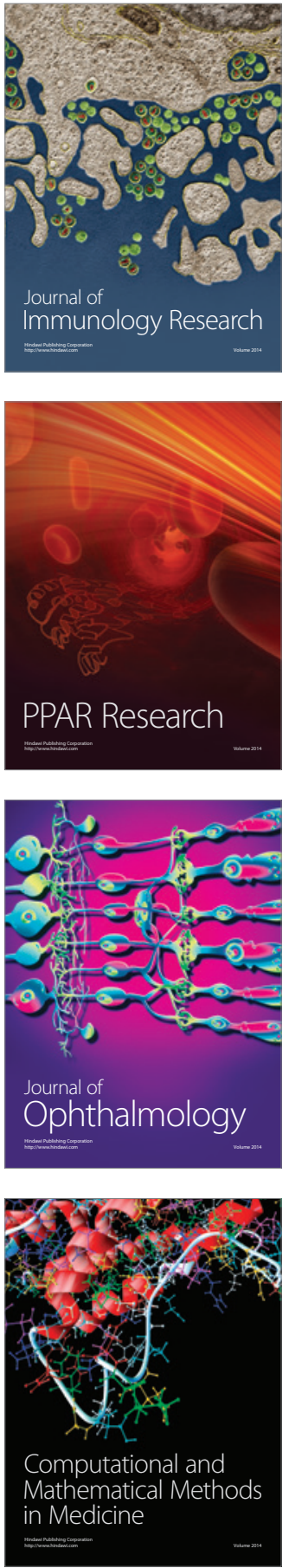

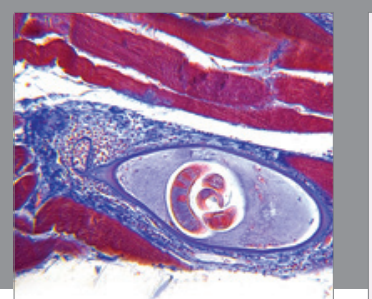

Gastroenterology Research and Practice

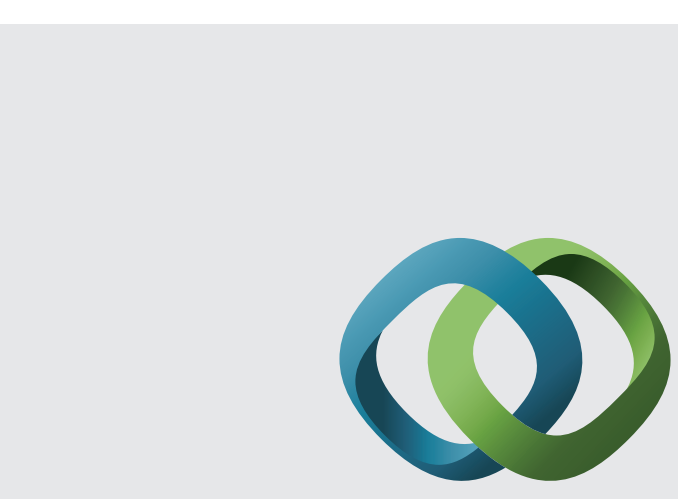

\section{Hindawi}

Submit your manuscripts at

http://www.hindawi.com
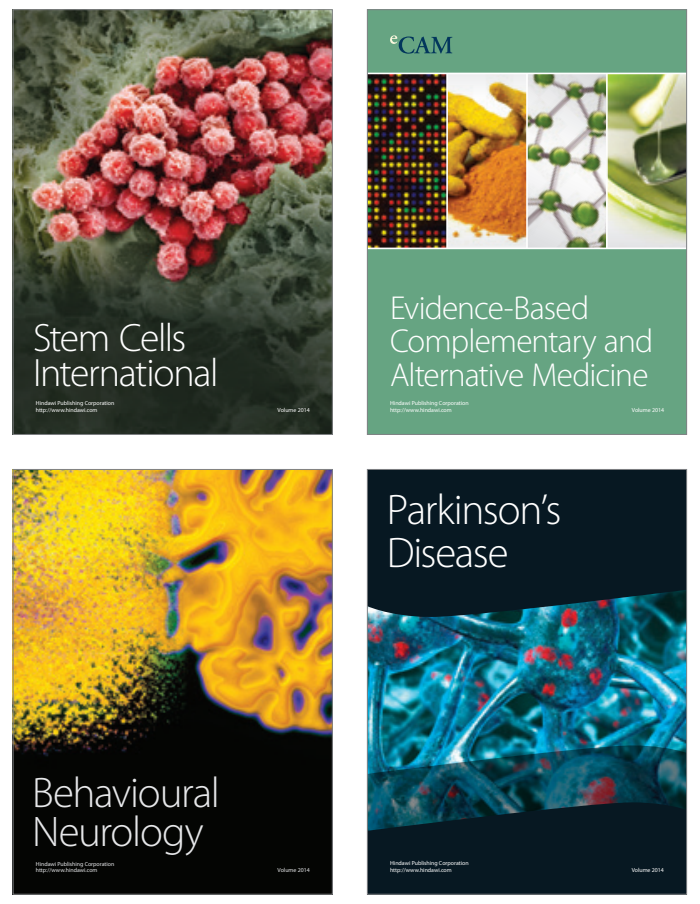
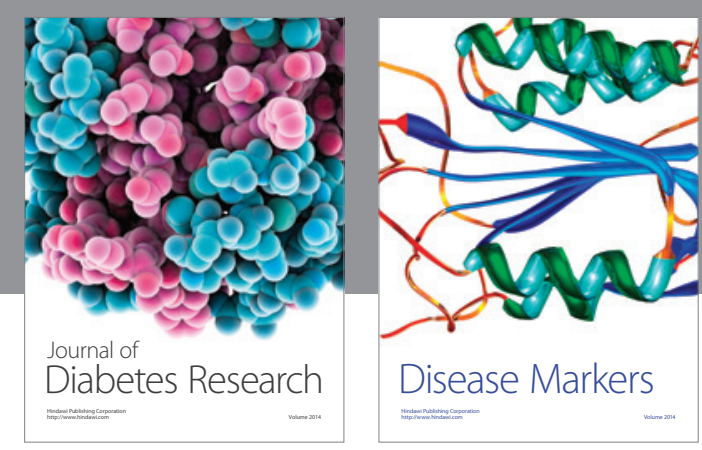

Disease Markers
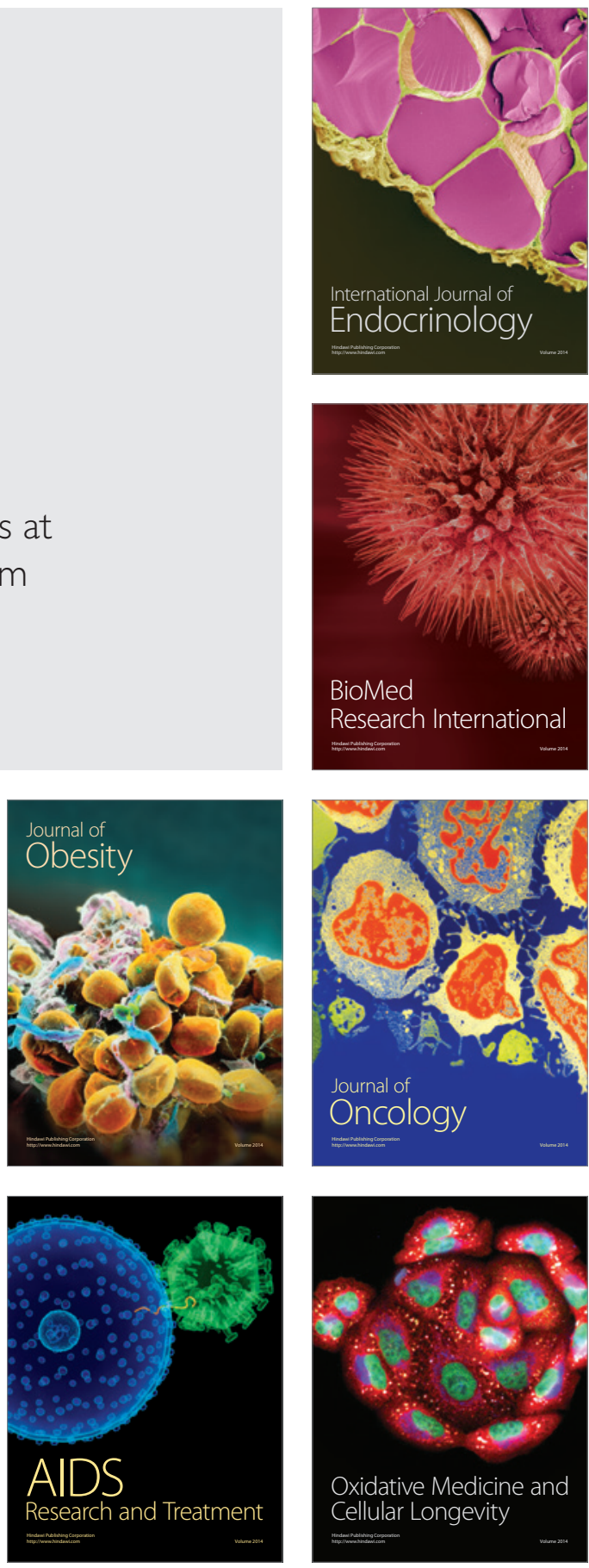